\title{
Dog Bites to Children in the Czech Republic: the Risk Situations
}

\author{
Jan Náhlík ${ }^{1}$, Eva Baranyiová2, Mojmír Tyrlík ${ }^{3}$ \\ ${ }^{1}$ Veterinary Clinic Panda, Prague, Czech Republic \\ ${ }^{2}$ Department of Veterinary Public Health and Toxicology, Faculty of Veterinary Hygiene and Ecology, \\ University of Veterinary and Pharmaceutical Sciences, Brno, Czech Republic \\ ${ }^{3}$ Department of Psychology, Faculty of Arts, Masaryk University, Brno, Czech Republic
}

Received September 12, 2008

Accepted September 21, 2010

\begin{abstract}
The aim of this study was to analyse dog bites to children in the Czech Republic. Data were obtained from a questionnaire completed with children aged 4 to 13 years in 11 urban and rural primary schools. A total of 103 dog bites sustained by 92 children were analysed using chi square test and $\mathrm{F}$ test. There were 58 boys $(56.3 \%)$ and 45 girls $(43.7 \%)$ bitten, $57.3 \%$ of them once, $42.7 \%$ repeatedly. The evaluated answers showed that children were bitten when playing with own dogs $(69.2 \%)$ or dogs known to them $(30.8 \%)$ but not by unknown dogs $\left(\chi^{2}=25.397\right.$, $\mathrm{df}=$ $1, p<0.001)$. Children were bitten outdoors by loose running unknown dogs $(88.5 \%)$, known dogs $(11.5 \%)$ but not by own dogs $\left(\chi^{2}=55.528\right.$, df $\left.=2, p<0.001\right)$. Thirty-two children were bitten indoors by small $(53.1 \%)$, medium size $(21.9)$ or large $(25.0 \%)$ dogs. Small dogs were biting mostly indoors $(51.5 \%)$, medium size $(73.1 \%)$ and large $(80.5 \%)$ dogs bit mostly outdoors $\left(\chi^{2}=9.0022, \mathrm{df}=2, p=0.011\right)$. Most of the children that disturbed a resting or sleeping dog were bitten indoors $\left(83.3 \% ; \chi^{2}=7.862, \mathrm{df}=1, p<0.01\right)$, predominantly by small dogs $\left(83.3 \%, \chi^{2}=\right.$ 7.482 , $\mathrm{df}=2, p=0.022)$. When stroking a dog, children were bitten by a medium size $(45.5 \%)$, large $(31.8 \%)$ or small $\operatorname{dog}\left(22.7 \% ; \chi^{2}=5.588\right.$, df $\left.=2, p<0.068\right)$. Children injured by their family-owned dog had accidentally caused pain to it before being bitten $\left(83.3 \% ; \chi^{2}=7.862\right.$, df $=$ $1, p<0.012)$. These children were always bitten by a small $\operatorname{dog}\left(\chi^{2}=7.482, \mathrm{df}=2, p=0.022\right)$. Three children reported deliberately causing pain to a dog - these were all small dogs $(100.0 \%$; $\left.\chi^{2}=6.279, \mathrm{df}=2, p<0.05\right)$. Children teasing dogs were bitten most frequently by a small $\operatorname{dog}\left(75.0 \% ; \chi^{2}=6.98, \mathrm{df}=2, p<0.032\right)$. Male dogs bit more frequently $(66.7 \%)$ than females $\left(33.3 \% ; \chi^{2}=6.338\right.$, d.f. $\left.=1, p=0.014\right)$. These data were the first ones obtained from the bitten children. They suggest that in interactions with own, known and small dogs, children were more daring. The personal space of dogs, their warning signals, and defence were underestimated, the resulting aggression was mostly of possessive, territorial and fear type. Additional suggestions are made to complete the information on preventive measures for parents, children and the public. Importantly, all information types should point out that the dog remains a predator despite its long domestication history and close co-existence with humans.
\end{abstract}

Questionnaire, boys, girls, dogs, risk factors, aggression, biting, size, sex, home, outdoors

Dog bites present an increasingly urgent public health problem in many countries. Dog bite injuries in children remain underrecognized and underreported and of particular concern since they are disproportionately represented in dog bite injury statistics (Kaye et al. 2009).

The most serious dog bites may end with death of the victims. In the USA, between 1979 and 1994, at least 279 people died after a dog attack. In 1995 and 1996, at least 25 people died following dog bites, and $80 \%$ of victims were children, 3 newborn babies younger than $30 \mathrm{~d}$, and one toddler aged 5 months, ten children were aged 1-4 years, six children were aged 5-11 years (Sacks et al. 2000).

The most frequent age of dog-bitten children is between 0 and 12 years, according to some authors up to 15 years. The average age of these victims was 5.2 to 9 years (Wright 1991; Hattaway 1997; Overall 1997; Rieck 1997; Weiss et al. 1998; Overall and Love 2001; Presutti 2001; Mitchell et al. 2003; Wilson et al. 2003; Feldman et 
al. 2004). In a Canadian study that evaluated 227 dog bites, adults represented $56 \%$ of the victims, and adolescents in the family were found to be a risk factor for dog bites (Guy et al. 2001bc). In Belgium, every year about $1 \%$ of the human population requires medical attention because of dog bites, and the numbers of bitten children are increasing (Anonymous 2005; De Keuster et al. 2006). In a Swiss study, victim-dog interactions prior to the incident were observed in children, especially in young infants and in family dog bites (Horisberger et al. 2004). In a comprehensive study carried out in Spain, males and children, particularly those aged 5-9 years were associated with dog bites (Rosado et al. 2009). A similar scenario is being reported from more and more countries.

As far as the biting dogs are concerned, most aggressive dogs were younger than one and two years, respectively (Rieck 1997; Guy et al. 2001ac). Up to 47\% of dogs aged 1-2 years were reported by their owners to be sometimes aggressive to people, both family members and strangers (Baranyiová et al. 2004). Most bite incidents occur in summer months and in the late afternoon hours when serotonin concentrations naturally decrease in the dog (Houpt 2005; Overall 1997; Akhtar et al. 2006; Kaye et al. 2009).

The biting dogs were mostly familiar to the victims (Raghavan 2008; Kaye et al. 2009), belonged to several specified breeds (Pit Bull, Pitbull mix, Rottweiler, Rottweiler mix, German Shepherd and GS mix, Akita), other and undefined breeds (Kaye et al 2009).

Localisation of bite wounds is dependent upon the age of the victims. The younger the victim, the more frequently the wounds are in the head and face area; in children younger than 4 years about 80\% (Matter 1998; Akhtar et al. 2006; Wake et al. 2006; Kaye et al. 2009). In children up to 9 years of age, the risk of head, face and neck wounds is high (e.g. Weiss et al. 1998; Feldmann et al. 2004; Ostanello et al. 2005). In the home environment, the upper part of the child's body is bitten more frequently, in public places outdoors mostly legs (Kahn et al. 2004). Boys aged 5 to 9 years had the highest dog bite incidence rate, 60.7 per 10000 persons (e.g. Weiss et al. 1998).

Since there were no data of this kind available in the Czech Republic, we decided to study the risk factors (types of child-dog interactions, dog size/breed, site of the accident) concerning both the children and dogs and thus contribute to the development of dog bite prevention programmes. Our study is in line with the call for such data from many countries (De Keuster 2004; Mills and Levine 2006; De Keuster et al. 2006) with the aim to form a broad basis for prevention programmes and reasonable legislation. However, our approach differed from other studies in that the victims of dog bites were interviewed directly. In this report, data concerning the biting dogs are presented.

\section{Materials and Methods}

Data for our study were obtained from a questionnaire developed for this purpose, after consultation with a psychologist (Náhlík 2005). The questions were simple and understandable for children, and tested on a group of 24 children that were not included in the study. The final version of the questionnaire was tested again and administered to all children by the same person (JN). Questions were formulated so as to provide information on the bitten children, on their relationship with the dogs, on the situation in which the incident happened, and on the outcome of the incident. The youngest children in kindergartens were asked the questions and the administrator recorded their answers. When identifying the size/breed of the dog, the children could select from variants of a small dog (up to $30 \mathrm{~cm}$ in withers, such as Yorkshire Terrier), medium size dog (30 to $50 \mathrm{~cm}$ - such as the English Cocker Spaniel) or a large dog, over $50 \mathrm{~cm}$ German Shepherd (drawings from Räber 1994 were used). The biting dogs were either own (i.e. owned by the child's family and living in the same household), known (e.g. belonging to friends, dogs that the child met occasionally) or unknown dogs (the child never met the dog before). The question on the bite site could be answered by pointing to the body part or by making a sign on a human body drawing attached to the questionnaire. For evaluation, the body parts were designated as head, neck, hands/arms (up to the shoulder), torso and feet/legs (including buttocks). There was a question asking the child to describe the circumstances of the bite incident. With this question we tried to obtain a possibly exact answer by asking the child further questions. No neuter status of the dogs was assessed.

Care was taken to approach only children that had no experience of dog bite prevention programmes. A total of 391 children were addressed in 11 primary schools in two urban and one rural area of various sizes (the city 
of Brno, the town Písek and township Protivín). Three age categories of children were addressed: 4-6 years (209 respondents), 8-9 years (50 respondents) and 12-13 years (132 respondents). In the study, only those children were included who upon direct questioning reported a dog bite in past. Biting was described as the situation when the teeth of a dog were in direct contact with the skin of the child, at least through his/her clothing. This distinction was made before filling out the questionnaire.

For statistical analysis of dog bite characteristics a set of data on 100 bite incidents was appropriate. The results were evaluated using the SPSS version 8 software and $\chi^{2}$ test and Fisher test were used.

\section{Children}

\section{Results}

Among 391 addressed children, 102 reported to have been bitten by a dog, i.e. $26 \%$. The children who reported to have been bitten were then given the questionnaire. However, ten of the questionnaires could not be evaluated because of formal errors or contradictory answers of the children. Thus 92 evaluated questionnaires concerned children who sustained a total of 103 bites; all bites were evaluated. Among the children who had had a dog bite experience, there were ten aged up to 6 years (pre-school), 25 were aged 8 to 9 years, and 68 were between 12 and 13 years (Fig. 1, Table 1).

Table 1. Age and sex of children that sustained dog bites

\begin{tabular}{|l|c|c|c|c|}
\hline Sex/Age of children & $4-6$ years & $8-9$ years & $12-13$ years & Total \\
\hline Boys & 5 & 14 & 39 & 58 \\
\hline Girls & 5 & 11 & 29 & 45 \\
\hline Total & 10 & 25 & 68 & 103 \\
\hline
\end{tabular}

The 103 evaluated answers show that 58 boys (56.3\%) and 45 girls (43.7\%) were bitten. The majority of children were bitten once $(57.3 \%)$, several were bitten more than once by the same $\operatorname{dog}(18.4 \%)$ and more than once by different dogs $\left(24.3 \%, \chi^{2}=4.743\right.$, d.f. $=2, p<0.099$. $)$

Sixty-one children $(59.2 \%)$ had a dog at home, more boys $(54.1 \%)$ than girls $(45.9 \%)$. A small dog was in the family of 25 bitten children (more often in a family with a boy, $64.0 \%$ ), middle size dog was in 15 families (60\% boys) and a large dog was owned by 21 families with bitten children (more often girls, 61.9\%). There were no significant differences between boys and girls in the numbers or sizes of family dogs.

Most children reported to have been growled at by a dog in past, more so boys $(60.4 \%)$ than girls $\left(39.6 \% ; \chi^{2}=4.401\right.$, d.f. $\left.=1, p<0.05\right)$. Growling was described as vocalization accompanied by baring teeth of the dog.

Bite circumstances, size and sex of biting dogs

Twenty-six children (25.7\%) were bitten when playing with a dog. With 98 valid answers no significant relationship was found with the age groups of bitten children. Dogs running loose outdoors bit $26(25.7 \%)$ children. Dogs that were disturbed in sleep bit 6 children $(5.9 \%)$. Dogs that were disturbed when eating bit 4 children (4.0\%). Seven children (6.9\%) ignored the growling of a dog and continued in activities that made the dog growl and eventually bite. Ten children $(9.9 \%)$ were bitten by a dog when approaching the dog's toy or tried to take the toy. Another 23 children (22.8\%) were bitten when patting/stroking a dog. Dogs bit 13 children $(12.9 \%)$ when they tried to take food or objects held by the children. In 4 cases $(4.0 \%)$ a child was bitten by unknown dog when defending his/her dog against it. Three children $(3.0 \%)$ caused deliberately pain to a dog and were in turn bitten by this dog. Another 6 children $(5.9 \%)$ accidentally caused pain to a dog and were bitten. Nine children $(8.9 \%)$ reported that they were bitten after they had teased/provoked a dog in different ways. Five children (5.0\%) were bitten by a dog that was defending its territory. From the 101 valid answers 5 children $(5.0 \%)$ were bitten in other situations and 3 children $(3.0 \%)$ did not remember the circumstances of the dog bite they sustained. When defending their own dog, children were most often bitten by an unknown $\operatorname{dog}\left(75.0 \%, \chi^{2}=4.265\right.$, d.f. $=2, p=$ n.s. $)$. 


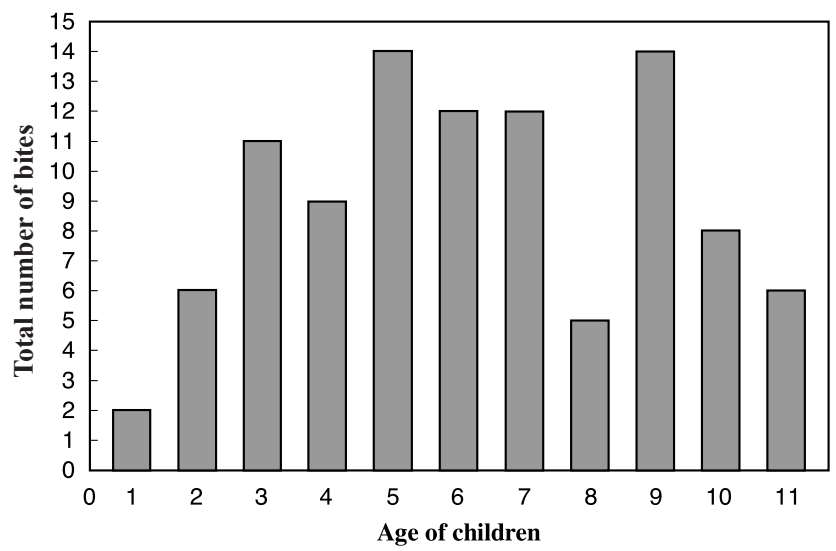

Fig. 1. Age of children when bitten by a dog

Other activities and interactions resulting in dog bites are shown in Table 2.

Table 2. Interactions of children and dogs that lead to bites

\begin{tabular}{|c|c|c|c|c|}
\hline $\begin{array}{l}\text { Activity that lead } \\
\text { to dog biting }\end{array}$ & $\begin{array}{c}\text { No. of } \\
\text { answers }\end{array}$ & Own dog \% & Known dog \% & Unknown dog \% \\
\hline $\begin{array}{l}\text { Child played } \\
\text { with dog }\end{array}$ & 101 & 69.2 & 30.8 & $\chi^{2}=25.397$, d.f. $=2, p<0.001$ \\
\hline $\begin{array}{l}\text { Loose running } \\
\text { dog bit a child in } \\
\text { a public place }\end{array}$ & 101 & 0 & 11.5 & $\chi^{2}=58.5 .528$, d.f. $=2, p<0.01$ \\
\hline $\begin{array}{l}\text { Child tried to take } \\
\text { away a toy }\end{array}$ & 101 & 30.0 & 70.0 & $\chi^{2}=6.804$, d.f. $=2, p<0.035$ \\
\hline $\begin{array}{l}\text { Child stroking } \\
\text { a dog }\end{array}$ & 101 & 17.4 & 56.5 & $26.1 \quad \chi^{2}=5.550$, d.f. $=2, p<0.055$ \\
\hline $\begin{array}{l}\text { Dog tried to take } \\
\text { food/items from child }\end{array}$ & 101 & 71.4 & 14.3 & $14.3 \quad \chi^{2}=11.113$, d.f. $=2, p<0.004$ \\
\hline
\end{tabular}

When evaluating the 101 answers concerning the site of a biting incident, the fact that a child was bitten in the house or outdoors was dependent upon the ownership of the dog. Dogs that belonged to the child's family bit more often in the home $(57.6 \%)$, dogs of the family friends bit more often during outdoors interactions $(62.2 \%)$ and unknown dogs bit exclusively outdoors $\left(100.0 \% ; \chi^{2}=24.796\right.$, d.f. $\left.=2, p<0.001\right)$.

The 102 valid answers indicated that dogs bit more frequently outdoors $(67.6 \%)$ than inside a house (32.4\%). Sixty answers revealed that male dogs bit more frequently outdoors (in $77.5 \%$ cases) compared to indoors $(22.5 \%)$ whereas females bit more often indoors $(55.0 \%)$ compared to outdoors $(45 \%)$. Male dogs bit more frequently $(66.7 \%)$ than females $(33.3 \%),\left(\chi^{2}=6.338\right.$, d.f. $\left.=1, p<0.014\right)$.

The 100 valid answers showed that 32 dogs bit indoors. In this number were $17(53.1 \%)$ small, $7(21.9 \%)$ medium size and $8(25.0 \%)$ large dogs. On the other hand, there were 68 dogs that bit outdoors, and among them were 16 (23.6\%) small, 19 (27.9\%) medium size and $33(48.5 \%)$ large dogs. Thus, small dogs bit more frequently indoors $(51.5 \%)$ whereas medium size dogs bit more often outdoors (73.1\%) as did also large dogs $(80.5 \%$; $\chi^{2}=9.022$, d.f. $\left.=2, p<0.011\right)$. 
A sleeping dog disturbed by a child bit at home $\left(83.3 \% ; \chi^{2}=7.862\right.$, d.f. $\left.=1, p<0.01\right)$. The 101 valid answers indicated that the children who unintentionally caused pain to a dog, were bitten at home $\left(83.3 \% ; \chi^{2}=7.862\right.$, d.f. $\left.=1, p<0.012\right)$.

Among 101 valid answers a small dog bit 34 children (33.7\%). A medium size dog bit 26 children (25.7\%), and a large dog bit 41 children (40.6\%). From 60 valid answers it follows that children who had a small dog at home were mostly bitten by a small dog $(60.0 \%)$, those who had a medium size dog at home, were mostly bitten by a medium size $\operatorname{dog}(53.3 \%)$ or by a large dog $(33.3 \%)$. Children who had a large dog at home were mostly bitten by a large dog $(80 \%)$. We found a relationship between the size of dogs owned by the family and the dogs that bit a child $\left(\chi^{2}=27.375\right.$, d.f. $\left.=4, p<0.001\right)$.

\section{Discussion}

Despite efforts in many countries to prevent/control dog bites (Houpt et al. 1996; Chapman et al. 2000; AVMA 2001; Wilson et al. 2003; Giusanni 2004; Jung 2004; Notari 2004; Osella et al. 2004; Pilonell 2004; Tissen et al. 2007), numbers of dog bite victims including the paediatric ones are rising (Sacks et al. 1996a; Akhtar et al. 2006; Langley 2009). Our study is therefore in line with calls for more information on dog bites (Mills and Levine 2006; De Keuster et al. 2006) in order to obtain data from many countries and prepare more efficient preventive programmes to protect potential victims, especially children.

In our group of children that sustained a dog bite, several previous findings were confirmed. The age categories of bitten children correspond to data by e.g. Sacks et al. (2000), Wilson et al. (2003); Akhtar et al. (2006); Kaye et al. (2009). Furthermore, in our survey, too, children were most frequently bitten by a known (i.e. not family-owned) dog, followed by own and unknown animals (Guy et al. 2001c; Presutti 2001; Kahn et al. 2003; Wilson et al. 2003; Akhtar et al. 2006; Kaye et al. 2009). According to Bernardo et al. (2002), children aged six years and less were more frequently bitten by the family dog than older children.

In our data set of 103 dog bites inflicted to 92 children, male victims prevailed similar to other reports (e.g. Akhtar et al. 2006; Wake et al. 2006; Kaye et al. 2009). In the study of Reisner et al. (2007), 6-year old children were bitten in association with resource guarding whereas older children were most commonly bitten in association with guarding territory. Our findings corroborate this description. Family dogs bit when children played with them or when they attempted to take food or objects from the child or when the children deliberately caused pain to them. On the other hand, known dogs bit when the children approached or tried to take the dog's toy or caused them pain by accident. Similar to Hart and Miller (1985) and Rieck (1997) we found that male dogs bit more frequently than female dogs; analysis of dog-dog bites revealed about $70 \%$ biting males and the most frequent injuries in these conflicts were those of the head region (Baranyiová et al. 2003) unlike injuries inflicted on children (Náhlík 2005).

The majority of children in our survey lived in a household with a dog (and/or other animals) (Náhlík 2005). Most of them reported that they were growled at by a dog in past. These facts indicate that the children were not instructed about the behaviour of the dog, its body language and warning signals. Our survey further showed that one quarter of the children were bitten when playing with dogs, others when stroking them, when disturbing them during rest, sleep or eating. Other situations were similar to those described by Reisner et al. (2007). The injuries were contracted mostly during indoor interactions in which small size dogs prevailed. In these situations supervision of children by adults could have prevented the bite (Cornwell 1997; Hattaway 1997; Spiegel 2000; Kahn et al. 2003). Toy and small breed dogs such as Chihuahua, Yorkshire Terrier, Fox Terrier, but 
also English Cocker Spaniel and Chow Chow are more reactive, aggressive and prone to snapping at children (Hart and Miller 1985; Hart and Hart 1985; 1997). Some breeds (Dachshunds, Chihuahuas, Jack Russel Terriers) appear to be aggressive in most contexts (Duffy et al. 2008). Dousek et al. (2001) have shown that the majority of biting dogs in the Czech Republic as reported to the State Veterinary Administration were mixed breed animals. Younger children are prone to facial injuries (Scheithauer and Rettinger 1997; Love and Overall 2001; Burroughs et al. 2002; Feldmann et al. 2004; Ostanello et al. 2005; Náhlík 2005; Kaye et al. 2009) and our results confirm this fact (Náhlík et al. 2006; 2007). Our data showed, too, that these incidents tend to happen inside (at home) when children interact with own or known dogs (Kahn et al. 2003). Our survey revealed that some children caused pain to dogs unintentionally but others deliberately teased and provoked the dogs by causing them pain as also reported by Akhtar et al. (2006). This fact deserves close attention since it may result from overall increasing aggressiveness of children exposed to violent video games connected with lower empathy and stronger proviolence attitudes (Funk 2006), and to media and cartoon violence (Kirsh 2006; Boxer et al. 2009).

Dogs and humans have had a close relationship for thousands of years and their partnership developed from their co-evolution (Schleidt and Shalter 2003). Communication between the two species is remarkable, yet not perfect. Both species may fail in this communication (Mills and de Keuster 2009).

We tend to forget that despite hundreds of dog generations selected and bred for many purposes the fact remains that people live in close proximity with predators, often in a small space, sharing with them their living quarters including beds (Baranyiová et al. 2005). Although dogs are not malicious (Mills and de Keuster 2009), unpredictability of their behaviour remains a factor that must always be taken into account. In the present study, aggression types described in veterinary literature (e.g. Houpt 2005), namely, possessive, territorial, predatory, and fear aggression were involved in the incidents.

Daily routines influence aggression, too, since dogs that spend more than $7 \mathrm{~h} /$ day inside a home were twice as likely to bite as those not allowed inside (Messam et al. 2008). Moreover, only a fraction of small dogs obtain any kind of training and their exercise is limited as well (Baranyiová et al. 2007, 2009). Such dogs may be predisposed to biting; in small dogs fear aggression may lead to biting. Several small breeds were found well above average for aggression and fear (Duffy et al. 2008). In this context the legal ban on selected dog breeds (Wapner and Wils on 2000; Mills and Levine 2006) seems to be questionable since dogs of any size and breed may bite.

Of paramount importance is family education of children and supervision of any child/ dog interactions. Most parents have no knowledge of canine behaviour (Reisner and Shofer 2008). Parents without proper information often purchase small breed dogs for their children, and both parents and children underestimate the risks involved in dealing with these dogs. However, it is not enough to teach the children how to deal with the dog, irrespective of its size, all interactions between young children and dogs must be closely supervised as most bites happen when there are no adults around (Kahn et al. 2003; Náhlík 2005). Only well informed parents can educate and supervise their children adequately.

This has been the aim of "The Blue Dog" CD project for home education of young children (Anonymous 2005) based on the work Dr. de Keuster and her team. The recent evaluation of the programme (Meints and de Keuster 2009) shows that children between 3 and 6 years of age are able to retain the information about safe conduct around house dogs for about two weeks and children practising with their parents performed better than those with verbal feedback only.

However, there is no doubt that any acquired knowledge and skills must be refined and reinforced in the family on a daily basis. It is necessary to teach the children appropriate 
behaviour when interacting with dogs and other animals. Intensive exposure to objective information on animals, learning about empathy, compassion, body language, growling, pain, viewing an animal as an animal, and not as a small brother or sister, should help to avoid frequent mistakes such as anthropomorphic approaches. Anticipatory guidance (Love and Overall 2001) similar to paediatric health care could prove useful in child-dog interactions.

Second important is the school environment. Several recent studies show the effects of social training and behavioural effects of the presence of dogs in the classroom, the correct types of interactions of children with dogs (Rud and Beck 2003; Kotrschal and Ortbauer 2003; Tissen et al. 2007). Good examples of educational interventions were reported by Chapman et al. (2000) and Wilson et al. (2003). It thus becomes increasingly clear that there is a potential and need to provide well structured education at primary and secondary schools in the Czech Republic; there are some singular attempts to do so by several organisations but these are not generally available and used to the full. A concentrated effort should result in appropriate obligatory form of education of children on how to behave and interact with animals in general, and dogs in particular.

The third factor is the role of veterinarians; they should be able to recommend a suitable breed or individual to prospective owners, advice the novice owners in how to deal with the puppy, organise puppy classes for their clients to prevent later behaviour problems. Families with small children should purchase/obtain puppies from a known and reliable source rather than dogs of unknown origin and socialisation history. For example, puppies from puppy mills may have behaviour problems and therefore such purchases should be discouraged. In this context, it is worth mentioning that being born at the owner's home was inversely related with biting in dogs (Messam et al. 2008). In puppy classes, children and puppies should be taught together the appropriate interactions and these should always be closely supervised by adults. Child-dog interactions leading to injuries and fatalities are often unsupervised (Raghavan 2008). All puppies should be thoroughly socialised and taught bite inhibition and food-bowl safety (Appleby et al. 2002; Luescher and Shaw 2003). Although later obedience training is helpful, it cannot prevent bites; $66 \%$ of 113 dogs involved in bites to children were taken to obedience classes (Reisner et al. 2007). Veterinarians should also be involved in school education programmes and provide a professional guarantee of quality information to children. Any information to families should contain a statement in an appropriate form about the predatory nature of dogs.

A similarly important role is the one of paediatricians and psychologists. Last but not least is a desirable community approach such as the AVMA (2001) initiative. However, to our knowledge, no results of this particular effort have been published.

In all countries a well functioning central register of dog bite incidents should exist as suggested by Weiss et al. (1998) and others, and permanent co-ordination and reporting between emergency medical departments and state veterinary authorities should be in place. It is known that vast majority of dog bites are never reported or medically treated (e.g. Sacks et al. 1996b). Statistics generated from these registers would be useful in assessing the efficiency of the preventive measures implemented.

Protection of human health, responsible dog ownership with a minimum of bite incidents, and an intact, functional human-animal bond with welfare of dogs preserved (Hun thau sen 1997) could thus be achieved.

\section{Pokousání dětí psy v České republice: rizikové situace}

Cílem studie bylo analyzovat pokousání dětí psy v České republice. Data jsme získávali z dotazníků, které vyplňovaly děti ve věku 4 až 13 let v 11 základních školách. Analyzovali jsme celkem 103 kousnutí, která utrpělo 92 dětí. Použili jsme k tomu chí kvadrát test 
a Fisherův F test. Pokousáno bylo 58 chlapců (56,3\%) a 45 dívek (43,7 \%), 57,3 \% z nich jednou, $42,7 \%$ opakovaně. Vyhodnocené odpovědi ukázaly, že děti byly pokousány při hře s vlastním $(69,2 \%)$ nebo známým psem $(30,8 \%)$, nikdy se psem neznámým $\left(\chi^{2}=25,397, \mathrm{df}=1, p<0,001\right)$. Pokousány byly venku volně pobíhajícími psy neznámými $(88,5 \%)$, známými $(11,5 \%)$ ale ne psy vlastními $\left(\chi^{2}=55,528\right.$, df $\left.=2, p<0,001\right)$. Třicet dvě děti byly pokousány v bytě psy malými $(53,1 \%)$, střední velikosti $(21,9 \%)$ nebo velkými $(25,0 \%)$. Malí psi kousali v bytě $(51,5 \%)$, středně velcí $(73,1 \%)$ a velcí psi $(80,5 \%)$ kousali nejčastěji venku $\left(\chi^{2}=9,0022\right.$, df $\left.=2, p=0,011\right)$. Většina dětí, které vyrušily psa při odpočinku anebo spánku, byla pokousána v domě $(83,3 \%$; $\left.\chi^{2}=7,862, \mathrm{df}=1, p<0.001\right)$, především psy malými $\left(83,3 \% ; \chi^{2}=7,482, \mathrm{df}=2\right.$, $p=0,022)$. Při hlazení psa byla většina dětí pokousána psy střední velikosti $(45,5 \%)$, velkými $(31,8 \%)$ nebo malými $\left(22,7 \% ; \chi^{2}=5,88, \mathrm{df}=2, p<0.068\right)$. Děti poraněné vlastním psem způsobily neúmyslně psovi bolest $\left(83,3 \% ; \chi^{2}=7,862\right.$, df $\left.=1, p<0.012\right)$. Tyto děti vždy pokousal pes malý $\left(\chi^{2}=7,482, \mathrm{df}=2, p=0.022\right)$. Třri děti uvedly, že psovi úmyslně způsobily bolest; pokaždé se jednalo o malého psa $\left(100,0 \% ; \chi^{2}=6,279\right.$, df $=2$, $p<0,05)$. Děti, které trápily psa, byly kousnuty psem malým, $\chi^{2}=6,98, \mathrm{df}=2, p<0.032$ ). Psi kousali častěji $(66,7 \%)$ než feny $\left(33,3 \% ; \chi^{2}=6,338, \mathrm{df}=1, p=0.014\right)$. Tyto údaje, první získané prímo od pokousaných dětí, ukazují, že v interakcích s vlastními, známými a malými psy byly děti troufalejší. Podceňovaly přitom osobní prostor psa, jejich varovné signály a obranu. Výsledkem byla agrese vlastnická, teritoriální a agrese ze strachu. $\mathrm{Na}$ základě získaných poznatků navrhujeme doplnit stávající informace o preventivních opatřeních pro rodiče, děti a veřejnost. Všechna doporučení by měla obsahovat upozornění o tom, že pes i přes dlouhou historii domestikace zůstává šelmou.

\section{Acknowledgement}

This study was in part supported by the MŠMT FRVŠ grant No. 2345/2006.

\section{References}

American Veterinary Medical Association 2001: A community approach to dog bite prevention. Task Force on Canine Aggression and Human-Canine Interaction. J Am Vet Med Assoc 218: 1732-1749

Akhtar N, Smith MJ, McKirs S, Page RE 2006: Surgical delay in the management of dog bite injuries in children: does it increase the risk of infection? Plast Reconstr Surg 59: 80-85

Anonymous 2005: Preventing dog bites with the help of the Blue Dog. Vet Rec 156: 499

Appleby DL, Bradshaw JWS, Casey R A 2002: Relationship between aggressive and avoidance behaviour by dogs and their experience in the first six months of life. Vet Rec 150: 434-438

Baranyiová E, Holub A, Janáčková B, Ernstová M 2001: Výpovědi chovatelů o psech v České republice. (Ownerreported behaviour of dogs in the Czech Republic, in Czech).Veterinářství 51:167-172

Baranyiová E, Holub A, Martiníková M, Nečas A, Zatloukal J 2003: Epidemiology of intraspecies bite wounds in dogs in the Czech Republic. Acta Vet Brno 72: 55-62

Baranyiová E, Holub A, Tyrlík M, Janáčková B, Ernstová M 2004: Behavioural differences of dogs of various ages in Czech households. Acta Vet Brno 73: 229-233

Baranyiová E, Holub A, Tyrlík M 2005: The influence of urbanization on the behaviour of dogs in the Czech Republic. Acta Vet Brno 74: 401-409

Baranyiová E, Holub A, Tyrlík M 2007: Behavioural traits of four dog breeds in Czech households. Acta Vet Brno 76: $627-634$

Baranyiová E, Holub A, Tyrlík M 2009: Body size and behaviour traits of dogs in Czech households. Acta Vet Brno 78: 107-114

Bernardo LM, Gardner MJ, Rosenfield RL, Cohen B, Pitetti R 2002: A comparison of dog bite injuries in younger and older children treated in a pediatric emergency department. Pediatr Emergency Care 18: 247-249

Boxer P, Huesmann LR, Bushman BJ, O'Brien M, Moceri D 2009: The role of violent media preference in cumulative developmental risk for violence and general aggression. J Youth and Adolescence 38: 417-428

Burroughs JR, Sopakar CN, Patrinely JR, Holck DE 2002: Periocular dog bite injuries and responsible care. Ophthalmic Plast Reconstr Surg 18: 416-419

Chapman S, Cornwall J, Righetti J, Sung L 2000: Preventing dog bites in children: randomised controlled trial of an educational intervention. Brit Med J 320: 1512-1513

Cornwell JM 1997: Dog bite prevention: Responsible pet ownership and animal safety. J Am Vet Med Assoc 210: $1147-1148$ 
De Keuster T 2004: ESVCE - Dog bite prevention project. In Proceedings of the $10^{\text {th }}$ European Congress on Companion Animal Behavioural Medicine, Cremona, Italy, 22-23 October 2004, p. 43-44

De Keuster T 2006: Epidemiology of dog bites: A Belgian experience of canine behaviour and public health concerns. Vet J 172: 482-487

Dousek J, Semerád Z, Vitásek J, Žertová H 2001: Veterinární problematika př́padů poranění člověka psem v České republice. Veterinářství 51: 112-115

Duffy DL, Hsu Y, Serpell JA 2008: Breed differences in canine aggression. Appl Anim Behav Sci 114: 441-460

Feldman KA, Trent R, Jay MT 2004: Epidemiology of hospitalizations resulting from dog bites in California, 1991-1998. Am J Public Health 94: 1940-1941

Funk JB 2006: Exposure to violent video games and desensitization to violence in children and adolescents. Lecture Notes in Computer Science 4161: 96-102

Giussani S 2004: Presentation of the ANMVI-SISCA project about the prevention of biting dogs. In Proceedings of the 10th European Congress on Companion Animal Behavioural Medicine, Cremona, Italy, 22 - 23 October, pp. 58-59

Guy NC, Luescher UA, Dohoo SE, Spangler E, Miller JB, Dohoo IR, Bate LA 2001a: Demographic and aggressive characteristics of dogs in a general veterinary caseload. Appl Anim Behav Sci 74: 15-28

Guy NC, Luescher UA, Dohoo SE, Spangler E, Miller JB, Dohoo IR, Bate LA 2001b: Risk factors for dog bites to owners in a general veterinary caseload. Appl Anim Behav Sci 74: 29-42

Guy NC, Luescher UA, Dohoo SE, Spangler E, Miller JB, Dohoo IR, Bate LA 2001c: A case series of biting dogs: characteristics of the dogs, their behaviour, and their victims. Appl Anim Behav Sci 74: 43-57

Hart BL, Hart LA 1985: Selecting pet dogs on the basis of cluster analysis of breed behavior profiles and gender. J Am Vet Med Assoc 186: 1181-1185

Hart BL, Hart LA 1997: Selecting, raising, and caring for dogs to avoid problem aggression. J Am Vet Med Assoc 210: $1129-1134$

Hart BL, Miller MF 1985: Behavioral profiles of dog breeds. J Am Vet Med Assoc 186: 1175-1180

Hattaway D 1997: Dogs and insurance. J Am Vet Med Assoc 210: 1143-1144

Houpt KA, Honig SU, Reisner IR 1996: Exploring the bond - Breaking the human companion animal bond J AmVet Med Assoc 208: 1653-1659

Houpt KA 2005: Domestic Animal Behavior. 4th Edition, Blackwell Publishing, Ames, 506 p.

Horisberger U, Stärck KDC, Rüfenacht J, Pillonel C, Steiger A 2004: The epidemiology of dig bite injuries in Switzerland - characteristics of victims, biting dogs and circumstances. Anthrozoos 167: 320-339

Hunthausen W 1997: Effects of aggressive behavior on canine welfare. J Am Vet Med Assoc 210: 1134-1136

Jung H 2004: Dog bite prevention: the dog in schools a model project in Bavaria, Germany. In Proceedings of the 10th European Congress on Companion Animal Behavioural Medicine, Cremona, Italy, 22 - 23 October, pp. 51-52

Kahn A, Bauche P, Lamoureux J 2003: Child victims of dog bites treated in emergency departments: a prospective survey. Eur J Pediatr 162: 254-258

Kaye AE, Belz JM, Kirchner RE 2009: Pediatric dog bite injuries: A 5-year review of the experience at the Children's Hospital of Philadelphia. Plast Reconstr Surg 124: 551-558

Kirsh SJ 2006: Cartoon violence and aggression in youth. Aggression and Violent Behavior 11: 547-557

Kotrschal K, Ortbauer B 2003: Behavioral effects of the presence of a dog in a classroom. Anthrozoos 16: $147-159$

Langley RL 2009: Human fatalities resulting from dog attacks in the United States, 1979-2005. Wilderness and Environ Med 20: 19-25

Love M, Overall KL 2001: How anticipating relationships between dogs and children can help prevent disasters. J Am Vet Med Assoc 219: 446-453

Luescher A, Shaw J 2003: Dogs! Principles and Techniques of Behavior Modification. Animal Behaviour Clinic, Center for Human - Animal Bond, SVM Purdue University. Course Materials, 492 p.

Matter HC 1998: The epidemiology of bite and scratch injuries by vertebrate animals in Switzerland. Eur J Epidemiol 14: 483-490

Meints K, de Keuster T 2009: Brief report: don't kiss a sleeping dog: the first assessment of "The Blue Dog” bite prevention programme. J Pediatr Psychol 34: 1084-1090

Messam LLM, Kass PH, Chomel BB, Hart LA 2008: The human-canine environment: A risk factor of non-play bites. Vet J 177: 205-215

Mills DS, Levine E 2006: The need for a co-ordinated scientific approach to the investigation of dog bite injuries. Vet J. 172: 398-399

Mills DS, De Keuster T 2009: Dogs in society can prevent society going to the dogs. Vet J 179: $322-323$

Mitchell RB, Nanez G, Wagner JD, Kelly J 2003: Dog bites of the scalp, face, and neck in children. Laryngoscope 113: 492-495

Náhlík J 2005: Výpovědi českých dětí o kousnutí psem (Czech children report on their dog bites), in Czech. MVDr. Thesis, VFU Brno, 74 p.

Náhlík J, Baranyiová E, Tyrlík M 2006: Dog bites to children in the Czech Republic - a survey. Proceedings, 31st World Congress WSAVA/FECAVA/CSAVA, Prague, pp. 872-873

Náhlík J, Baranyiová E, Tyrlík M 2007: Children and dogs - bites in various situations. F. Galindo, L. Alvarez (Eds): Proceedings of the $41^{\text {st }}$ International Congress of the ISAE. Mérida, Mexico, 2007, p. 76. 
Notari L 2004: Educating children in their relationship with dogs: The role of veterinary behaviourists in school. In Proceedings of the 10th European Congress on Companion Animal Behavioural Medicine, Cremona, Italy, 22-23 October, pp. 48-50

Osella MC, Panichi M, Cedolini D, Berno S 2004: A multidisciplinary educational project: A pilot project in a primary school and in a kindergarten. In Proceedings of the 10th European Congress on Companion Animal Behavioural Medicine, Cremona, Italy, 22 - 23 October, pp. 53-54

Ostanello F, Gherardi A, Caprioli A, La Placa L, Passini A, Prosperi S 2005: Incidence of injuries caused by dogs and cats treated in emergency departments in a major Italian city. Emergency Med J 22: 260-262

Overall KL 1997: Clinical Behavioral Medicine for Small Animals. Mosby, St. Louis, 544 p.

Overall KL, Love M 2001: Dog bites to humans - demography, epidemiology, injury and risk. J Am Vet Med Assoc 218: 1923-1934

Pillonel C 2004: Ongoing pilot projects in Swiss schools to prevent dog-bite incidents. In Proceedings of the 10th European Congress on Companion Animal Behavioural Medicine, Cremona, Italy, 22 - 23 October. pp. 55-57

Presutti J 2001: Prevention and treatment of dog bites. American Family Physician 63: 1567-1572

Räber H 1994: Encyklopedie - plemena psů. (Encyclopedia - dog breeds). První české vydání. BLESK: 911 p.

Raghavan M 2008: Fatal dog attacks in Canada, 1990-2007. Can Vet J 49: 577-581

Reisner IR, Shofer FS, Nance ML 2007: Behavioral assessment of child-directed canine aggression. Injury Prevention 13: 348-351

Reisner IR, Shofer FS 2008: Effects of gender and parental status on knowledge and attitudes of dog owners regarding dog aggression toward children. J Am Vet Med Assoc 233: 1412-1419

Rieck D 1997: Dog bite prevention from animal controls perspective. J Am Vet Med Assoc 210: 1145-1146

Rosado B, Belenguer SG, León M, Palacio J 2009: A comprehensive study of dog bites in Spain, 1995-2004. Vet J 179: $383-391$

Rud AG, Beck AM 2003: Companion animals in Indiana elementary schools. Anthrozoos 16: 241-251

Sacks JJ, Lockwood R, Hornreich J, Sattin R. 1996a: Fatal dog attacks, 1989-1994. Pediatrics 97: 891-895

Sacks JJ, Krewnow M, Houston B1996b: Dog bites: how big a problem? Injury Prev 2: $52-54$

Sacks JJ, Sinclair L, Gilchrist J, Golab GC, Lockwood R 2000: Breeds of dogs involved in fatal human attacks in the United States between 1979 and 1998. J Am Vet Med Assoc 217: 836-840

Scheithauer MO, Rettinger G 1997: Bite injuries in the head and neck region. HNO 45: 891-897

Schleidt WM, Shalter MD 2003: Co-evolution of humans and canids: an alternative view of dog domestication. Homo homini lupus? Evolution Cognition 9: 57-72

Spiegel IB 2000: A pilot study to evaluate an elementary school-based dog bite prevention program. Anthrozoos 13: $164-173$

Tissen I, Hergovich A, Spiel C 2007: School-based social training with and without dogs: Evaluation of their effectiveness. Anthrozoos 20: 365-373

Wake AAF, Stafford KJ, Minot EO 2006: The experience of dog bites: A survey of veterinary science and veterinary nursing students. New Zealand Vet J 54: 141-146

Wapner M, Wilson JF 2000: Are laws prohibiting ownership of pit bull-type dogs legally enforcable? J Am Vet Med Assoc 216: 1552-1554

Weiss HB, Friedman DI, Coben JH 1998: Incidence of dog bite injuries treated in emergency departments. J Am Med Assoc 279: 51-53

Wilson F, Dwyer F, Bennett PC 2003: Prevention of dog bites: Evaluation of a brief educational intervention program for preschool children. J Community Psychol 31: 75-86

Wright JC 1991: Canine aggression toward people. Advances in Companion Animal Behavior. Vet Clin North Am: Small Animal Practice, vol 21: 299-314 